\title{
PENDAPATAN DAN KESEJAHTERAAN RUMAH TANGGA PEMBUDIDAYA LELE DI KECAMATAN NATAR KABUPATEN LAMPUNG SELATAN
}

\author{
(Income and Welfare of Catfish Cultivators Househols in Natar Sub District, South Lampung Regency)
}

Faakhira Nadia Syakina, Yaktiworo Indriani, Muhammad Irfan Affandi

\begin{abstract}
Jurusan Agribisnis, Fakultas Pertanian, Universitas Lampung, Jl. Prof. Dr. Soemantri Brojonegoro No. 1 Bandar Lampung, 35145. Telp. 089632345587, e-mail: yaktiworo.indriani@fp.unila.ac.id
\end{abstract}

\begin{abstract}
This research aims to analyze the contribution of catfish cultivation enlargement to household income and the welfare of catfish cultivators household. The research data was collected in Sub-District of Natar of South Lampung regency in December 2017 - January 2018. Respondents in this research were 30 cultivators of catfish enlargement, chosen on purpose for they have been actively running their business and 4 expert people in catfish cultivation. Primary data was obtained by interviewing the respondents, while secondary data was obtained from several related institutions. Collected household income was included cultivation income of catfish, off-farm income, and non-farm income. The level of household welfare was analyzed by three criterias namely Sajogyo, Badan Pusat Statistik (BPS) and Badan Kependudukan dan Keluarga Berencana Nasional (BKKBN). The result showed that the average income of catfish cultivators business contributed 44,27 percent of the total household income of Rp52.340.376,00 per year. The household welfare level based on Sajogyo showed that 20 percent of households were in the almost-poor category, 50 percent in moderate, and 30 percent in decent living class. Based on BPS and BKKBN category showed that 20 percent of households were in the less prosperous and 80 percent were prosperous.
\end{abstract}

Key words: catfish, income, welfare

\section{PENDAHULUAN}

Banyak jenis ikan air tawar yang umum dikonsumsi masyarakat di antaranya adalah ikan lele, ikan mas, ikan gurame, ikan mujair, ikan nila, dan lain-lain. Menurut data Dinas Kelautan dan Perikanan Provinsi Lampung (2017a), pada tahun 2016 produksi ikan tertinggi di Provinsi Lampung adalah jenis lele. Hingga saat ini lele masih menjadi komoditas andalan budidaya air tawar di Provinsi Lampung yang menyumbang angka tertinggi sebesar 48,14 persen dari total produksi ikan air tawar. Hal ini karena pada tahun 2015 2016 produksi lele di Provinsi Lampung mengalami peningkatan sebesar 790,13 persen.

Menurut data Dinas Kelautan dan Perikanan Lampung Selatan (2017a), pada tahun 2016 Kecamatan Tanjung Bintang merupakan daerah penghasil lele terbesar di Kabupaten Lampung Selatan yaitu sebesar 60,47 persen. Hal ini didukung oleh lokasi Kecamatan Tanjung Bintang yang dekat dengan Kota Bandar Lampung sebagai pusat pasar yang menyediakan berbagai fasilitas produksi dan ketersediaan pasar yang luas. Kecamatan Natar menempati urutan ke enam dalam produksi lele di Lampung Selatan yaitu sebesar 1,10 persen. Jumlah produksi di kedua daerah tersebut sangat bertolak belakang jika dilihat dari kesamaan lokasinya yang dekat dengan Kota Bandar Lampung. Menurut Pemerintah Kota Bandar Lampung (2017), Kecamatan Natar adalah daerah di Kabupaten Lampung Selatan yang berbatasan langsung di sebelah utara Kota Bandar Lampung dan Kecamatan Tanjung Bintang berbatasan langsung di sebelah Timur Kota Bandar Lampung.

Menurut data Dinas Kelautan dan Perikanan Kabupaten Lampung Selatan (2017b) jumlah pembudidaya lele menurun sebesar 52 persen pada tahun 2017. Alasan pembudidaya mulai meninggalkan usaha tersebut adalah besarnya biaya produksi dan pendapatan usaha budidaya yang rendah. Kendala yang sering dihadapi dalam peningkatan produksi dan pendapatan pembudidaya adalah keterbatasan pembudidaya dalam mengalokasikan faktor-faktor produksi yang ada sehingga pencapaian produktivitas belum optimal. Semakin rendah kontribusi pendapatan usaha budidaya lele terhadap pendapatan rumah tangga, maka akan semakin rendah pula kemampuan usaha budidaya ini untuk menopang kesejahteraan pembudidaya. Hal tersebut selanjutnya akan bepengaruh terhadap taraf hidup pembudidaya, dimana semakin rendahnya 
pendapatan rumah tangga maka akan semakin dekat rumah tangga tersebut dengan kemiskinan. Berdasarkan masalah yang telah diuraikan, maka tujuan penelitian ini adalah menganalisis kontribusi pendapatan usaha budidaya lele terhadap pendapatan dan tingkat kesejahteraan rumah tangga pembudidaya lele di Kecamatan Natar Kabupaten Lampung Selatan.

\section{METODE PENELITIAN}

Penelitian ini dilaksanakan di Kecamatan Natar yang dipilih secara sengaja (purposive). dengan pertimbangan bahwa Kecamatan Natar adalah daerah yang berbatasan langsung dengan Kota Bandar Lampung. Kota Bandar Lampung adalah Ibukota Provinsi Lampung dan lokasi pusat pasar yang menyediakan berbagai kebutuhan untuk budidaya lele.

Metode yang digunakan dalam penelitian ini adalah metode survai. Metode ini dilakukan dengan pengamatan dan wawancara langsung menggunakan kuesioner yang berisi daftar pertanyaan. Data penelitian terdiri dari data primer dan data sekunder. Data primer didapatkan dari penelitian, sedangkan data sekunder didapatkan dari literature dan instansi terkait. Penelitian ini dibagi menjadi dua tahap, tahap pertama yaitu pengumpulan data terkait dengan pendapatan dan kesejahteraan pembudidaya lele. Tahap kedua yaitu identifikasi faktor internal dan eksternal dalam usaha budidaya lele di Kecamatan Natar.

Metode penentuan sampel dalam penelitian ini adalah non probability sampling. Dalam penelitian ini tidak semua kelompok budidaya lele (pokdakan) di Kecamatan Natar dijadikan responden. Hal ini dilakukan dengan pertimbangan bahwa tidak semua pokdakan lele di Kecamatan Natar aktif secara konsisten dan kontinyu melakukan budidaya. Berdasarkan pertimbangan tersebut maka dipilih tiga pokdakan yaitu pokdakan Tunas Harapan 12 orang, Cipta Mina Lestari 10 orang, dan Citra Mina Lestari 8 orang. Lokasi pokdakan tersebut secara berturutturut yaitu Desa Tanjung Bintang, Desa Pancasila, dan Desa Sukadamai.

Analisis pendapatan usaha budidaya menggunakan analisis BEP dan $\mathrm{R} / \mathrm{C}$ rasio. Analisis kontribusi pendapatan usaha budidaya terhadap pendapatan rumah tanggga menggunakan persentase perbandingan antara pendapatan usaha budidaya lele, pendapatan usahatani di luar lele, dan pendapatan di luar pertanian. Analisis tingkat kesejahteraan menggunakan kriteria Sajogyo,

Badan Pusat Statistik (BPS), dan Badan Kependudukan dan Keluarga Berencana Nasional (BKKBN) .

Menurut Soekartawi (1995), pendapatan usahatani dapat ditulis sebagai berikut.

$\mathrm{Pd}=\mathrm{TR}-\mathrm{TC}=(\mathrm{Y} . \mathrm{Py})-\left(\sum \mathrm{Xi} \cdot \mathrm{Pxi}+\mathrm{FC}\right)$

Keterangan :

$\mathrm{Pd}=$ Pendapatan usahatani

$\mathrm{TR}=$ Total penerimaan $(\mathrm{Rp})$

$\mathrm{TC}=$ Total biaya $(\mathrm{Rp})$

$\mathrm{Xi}=$ Faktor produksi variabel ke-i

$\mathrm{Pxi}=$ Harga produksi variabel ke-i $(\mathrm{Rp})$

$\mathrm{Y}=$ Produksi $(\mathrm{kg})$

$\mathrm{Py}=$ Harga produksi $(\mathrm{Rp})$

$\mathrm{FC}=$ Biaya tetap total $(\mathrm{Rp})$

Menurut Rahim dan Hastuti (2008), untuk mengetahui imbangan penerimaan dan biaya.

$\mathrm{R} / \mathrm{C}=\mathrm{TR} / \mathrm{TC}$

Keterangan :

$\mathrm{R} / \mathrm{C}=$ Nisbah penerimaan

Rumus titik impas atau Break Even Point menurut Suratiyah (2015) adalah sebagai berikut.

$\mathrm{BEP}_{\text {penerimaan (Rp) }}=\frac{F C}{1-\frac{V C}{S}}$

$\mathrm{BEP}_{\text {unit }(\mathrm{kg})}=\frac{\text { BEP Penerimaan }}{P x}$

Menurut Supriyono (2001) perhitungan BEP harga per unit adalah sebagai berikut.

$\mathrm{BEP}_{\text {harga }(\mathrm{Rp} / \mathrm{kg})}=\frac{\mathrm{TC}}{\mathrm{Y}}$

Keterangan :

$\mathrm{S}=$ Penerimaan $(\mathrm{Rp})$

$\mathrm{VC}=$ Biaya biaya variabel $(\mathrm{Rp})$

$\mathrm{Px}=$ Harga Produk $\mathrm{x}(\mathrm{Rp})$

Pendapatan rumah tangga dan kontribusi pendapatan budidaya terhadap pendapatan rumah tangga secara sistematis adalah sebagai berikut.

$\mathrm{P}_{\mathrm{RT}}=\left(\mathrm{P}_{\mathrm{usaha} \text { budidaya }}+\mathrm{P}_{\text {non usaha budidaya }}\right)+\mathrm{P}_{\text {non pertanian }}$ 
Keterangan :

$\mathrm{P}_{\mathrm{RT}} \quad=$ Pendapatan rumah tangga

Kontribusi Pendapatan Usaha Budidaya

$$
=\frac{\text { Pendapatan usaha budi daya }}{\text { Pendapatan RT }} \times 100 \%
$$

\section{Kesejahteraan Rumah Tangga}

Dalam perhitungan tingkat kesejahteraan menurut Sajogyo (1997) maka terlebih dahulu dihitung total pengeluaran rumah tangga harian, mingguan, bulanan, dan tahunan. Secara sistematis pengeluaran (C) perhitungan tingkat kesejahteraan dapat ditulis sebagai berikut.

$$
\mathrm{C} / \text { kapita/tahun }(\mathrm{Rp})=\frac{\mathrm{c}}{\sum \text { anggota keluarga }} \ldots \ldots
$$

C/kapita/setara beras $(\mathrm{kg})$

$$
=\left(\frac{\mathrm{c}}{\text { Kapita }} / \text { tahun }\right): \text { harga beras }
$$

Klasifikasi kemiskinan menurut indikator Sajogyo digolongkan sebagai berikut.

1. Paling miskin, jika $\mathrm{C}$ per anggota keluarga $\geq 180 \mathrm{~kg}$ setara nilai beras/tahun.

2. Miskin sekali, jika $\mathrm{C}$ per anggota keluarga antara $181-240 \mathrm{~kg}$ setara nilai beras/tahun.

3. Miskin, jika $\mathrm{C}$ per anggota keluarga antara 241 $-320 \mathrm{~kg}$ setara nilai beras/tahun.

4. Nyaris miskin, jika C antara $321-480 \mathrm{~kg}$ setara nilai beras/tahun.

5. Cukup, jika $\mathrm{C}$ per anggota keluarga antara 481 - $960 \mathrm{~kg}$ setara nilai beras/tahun.

6. Hidup layak, jika $\mathrm{C}$ per anggota keluarga lebih dari $960 \mathrm{~kg}$ setara nilai beras/tahun.

Analisis kesejahteraan menurut BPS (2014) dilakukan dengan mengukur beberapa indikator yaitu kependudukan, kesehatan dan gizi, pendidikan, ketenagakerjaan, taraf dan pola konsumsi, perumahan dan lingkungan, sosial dan lain-lain.

$\mathrm{RS}=\frac{\mathrm{SkT}-\mathrm{SkR}}{\mathrm{JK} 1}$

Keterangan :

RS = Range skor

SkT $=$ Skor tertinggi $(7 \times 3=21)$

SkR $=$ Skor terendah $(7 \times 1=7)$

$\mathrm{JKl}=$ Jumlah klasifikasi yang digunakan (2)
Hubungan antara interval skor dan tingkat kesejahteraan adalah sebagai berikut.

1. Skor antara $7-14=$ Rumah tangga pembudidaya lele belum sejahtera.

2. Skor antara $15-21=$ Rumah tangga pembudidaya lele sudah sejahtera.

Kesejahteraan menurut BKKBN (2011) dibagi ke dalam lima tahapan keluarga yaitu sebagai berikut.

a. Keluarga Pra Sejahtera = belum dapat memenuhi salah enam indikator dasar yang terdiri dari pangan, sandang, papan, kesehatan, dan pendidikan.

b. Keluarga Sejahtera $I=$ telah memenuhi indikator dasar. Tetapi belum memenuhi indikator psikologis yang terdiri dari melaksanakan ibadah, konsumsi protein, pakaian baru, luas rumah yang mencukupi, kondisi sehat, pekerjaan, kemampuan baca tulis, dan kontrasepsi.

c. Keluarga Sejahtera II = telah memenuhi kebutuhan dasar dan psikologis, tetapi belum memenuhi kebutuhan perkembangan. Indikator kebutuhan tersebut meliputi peningkatkan pengetahuan agama, tabungan penghasilan, berkomunikasi pada saat makan bersama, ikut kegiatan sosial di lingkungannya, dan mudah mengakses informasi melalui media.

d. Keluarga Sejahtera III = telah memenuhi kebutuhan dasar, psikologis, dan perkembangannya. Tetapi belum memenuhi kebutuhan aktualisasi diri yang meliputi pemberian sumbangan materiil untuk kegiatan sosial secara rutin dan aktif sebagai pengurus perkumpulan sosial masyarakat.

e. Keluarga Sejahtera III plus = telah memenuhi kebutuhan dasar, psikologis, perkembangan, dan aktualisasi diri.

\section{HASIL DAN PEMBAHASAN}

\section{Karakteristik Responden}

Seluruh responden pada penelitian ini berada pada usia produktif yaitu antara $15-64$ tahun. Sebagian besar responden berada pada usia $41-50$ tahun yaitu sebesar 46,47 persen. Rata-rata jenjang pendidikan responden adalah Sekolah Menengah Atas (SMA) yaitu sebesar 47,47 persen. Sebesar 76,67 persen pembudidaya lele yang dijadikan responden menjalani pendidikan lebih dari atau sama dengan sembilan tahun. Sebesar 57,67 persen responden merupakan pembudidaya pemula dengan pengalaman kurang dari lima tahun. 
Sebanyak 33 persen responden menjadikan usaha budidaya lele sebagai pekerjaan utama, sedangkan 67 persen lainnya merupakan pekerjaan sampingan. Sebesar 46,67 persen pembudidaya lele di Kecamatan Natar memiliki pekerjaan lain yang masih dalam lingkup pertanian. Pekerjaan dalam lingkup pertanian di luar usaha budidaya lele terdiri dari petani jagung, padi, dan perkebunan, peternak, serta tengkulak. Pekerjaan diluar lingkup pertanian tersebut terdiri dari pedagang, guru, Pegawai Negeri Sipil, karyawan swasta, dan montir.

Sebagian besar $(43,33 \%)$ jenis kolam yang dimiliki responden adalah kolam terapal. Hanya sebanyak 26,66 persen pembudidaya yang memiliki luas kolam lebih besar atau sama dengan $110 \mathrm{~m}^{2}$. Sehingga dapat dikatakan bahwa usaha budidaya lele di Kecamatan Natar merupakan usaha perikanan skala kecil.

\section{Biaya dan Pendapatan Usaha Budidaya Lele}

Lele dipanen saat berumur 60 hari setelah pembesaran dengan bobot antara $80-100$ gram per ekor atau $10-12$ ekor per kilogram. Produksi rata-rata adalah $1.444 \mathrm{~kg}$ per musim tebar. Produktivitas tertinggi adalah kepadatan tebar 246,90 - 251,95 ekor per $\mathrm{m}^{2}$ dan pakan sebesar 0,09 kilogram per ekor benih. Harga rata-rata lele adalah Rp15.416,67 per kg. Penerimaan diperoleh dari hasil produksi dikali dengan harga ikan lele. Penerimaan rata-rata usaha budidaya lele untuk satu kali musim tebar adalah Rp22.089.017 untuk luas kolam rata-rata $111 \mathrm{~m}^{2}$.

Biaya produksi terdiri dari biaya tetap dan biaya variabel. Biaya tertinggi pada usaha budidaya ini adalah biaya variabel pakan pellet yaitu 64,51 persen dari total biaya produksi. Hal ini sejalan dengan penelitian Susant, Lestari dan Kasymir (2017) bahwa biaya pakan pellet merupakan biaya tertinggi dari usaha budidaya ikan. Penggunaan tenaga kerja rata-rata pada usaha budidaya ini adalah 11,12 HKP per musim tebar yang terdiri dari 6,90 tenaga kerja dalam keluarga (TKDK) dan 4,22 tenaga kerja luar keluarga (TKLK). Upah tenaga kerja rata-rata adalah Rp50.000,00 per hari.

Total biaya rata-rata yang dikeluarkan untuk satu kali perode tebar adalah Rp15.262.508,21 yang terdiri dari Rp12.849.073,60 biaya tunai dan Rp2.413.434,62 biaya diperhitungkan. Pendapatan diperoleh dari selisih antara penerimaan dan biaya produksi. Pendapatan rata-rata atas biaya tunai adalah Rp9.412.593,07 dan pendapatan rata-rata atas biaya total adalah Rp6.999.158,46. Data biaya dan pendapatan rata-rata secara lengkap dapat dilihat pada Tabel 1.

Produksi dan penerimaan usaha budidaya lele per musim tebar untuk lahan seluas $111 \mathrm{~m}^{2}$ telah melebihi nilai BEP unit dan BEP penerimaan. Hal ini berarti dari segi produksi dan penerimaan usaha ini menguntungkan. Harga jual rata-rata lele per kilogram telah melebihi nilai BEP harga, hal ini berarti dari segi harga usaha ini menguntungkan.

Nilai R/C rasio atas biaya tunai pada usaha budidaya lele di Kecamatan Natar Kabupaten Lampung Selatan untuk lahan seluas $111 \mathrm{~m}^{2}$ adalah 1,73 . R/C rasio usaha budidaya lele di Kabupaten Muara Jambi pada penelitian Febriyanti (2013) menunjukkan nilai yang lebih rendah yaitu sebesar 1,28 atas biaya tunai. Nilai $\mathrm{R} / \mathrm{C}$ rasio $>1$ menunjukkan bahwa usaha tersebut layak dijalankan. Hal ini berarti bahwa usaha budidaya lele menguntungkan dan dapat menjadi pertimbangan dalam pemilihan bidang usaha.

Tabel 1. Penerimaan, Biaya, Pendapatan, BEP dan $\mathrm{R} / \mathrm{C}$ rasio usaha budidaya lele di Kecamatan Natar Kabupaten Lampung Selatan

\begin{tabular}{|c|c|c|}
\hline \multirow{2}{*}{ Uraian } & \multicolumn{2}{|l|}{$111 \mathrm{~m}^{2}$} \\
\hline & Nilai (Rp) & $(\%)$ \\
\hline A. Penerimaan & $22.234 .944,44$ & \\
\hline \multirow{2}{*}{\multicolumn{3}{|c|}{$\begin{array}{l}\text { Harga Jual : Rp } 15.416,67 \\
\text { Produksi : } 1.442,27 \mathrm{~kg}\end{array}$}} \\
\hline & & \\
\hline \multicolumn{3}{|l|}{ B. Biaya Variabel } \\
\hline 1. Biaya Benih & $2.438 .628,89$ & 15,98 \\
\hline 2. Biaya Pakan Pellet & $9.846 .532,47$ & 64,51 \\
\hline 3. Biaya Pakan Alternatif & $104.133,33$ & 0,68 \\
\hline 4. Biaya Pupuk & $76.388,56$ & 0,50 \\
\hline 5. Biaya Antibiotik & $44.807,02$ & 0,29 \\
\hline 6. Biaya Probiotik & $16.083,00$ & 0,11 \\
\hline 7. Biaya TKLK & $211.000,00$ & 1,38 \\
\hline 8. Biaya Listrik/BBM & $114.000,00$ & 0,83 \\
\hline 9. Biaya TKDK & $345.220,83$ & 2,51 \\
\hline Total Biaya Variabel & $13.196 .794,00$ & 86,47 \\
\hline \multicolumn{3}{|l|}{ C. Biaya Tetap } \\
\hline 1. Biaya Sewa Lahan & $77.863,00$ & 0,51 \\
\hline \multicolumn{3}{|l|}{ 2. Biaya Penyusutan (th): } \\
\hline a. Kolam dan Mesin & $1.278 .707,95$ & 8,38 \\
\hline b. Peralatan & $709.142,50$ & 5,02 \\
\hline Total Biaya Tetap & $2.065 .714,78$ & 13,40 \\
\hline Total Biaya & $15.262 .508,21$ & 100,00 \\
\hline BEP Penerimaan(Rp) & $5.073 .014,87$ & \\
\hline BEP Unit (Kg) & 329,06 & \\
\hline BEP Harga (Rp/unit) & $10.582,28$ & \\
\hline Pendapatan Tunai (Rp) & $9.412 .593,07$ & \\
\hline Pendapatan Total (Rp) & $6.999 .158,46$ & \\
\hline R/C Tunai & 1,73 & \\
\hline R/C Total & 1,46 & \\
\hline
\end{tabular}


Jika dikonversikan dalam satuan per hektar, usaha budidaya lele di Kecamatan Natar menunjukkan nilai BEP lebih kecil. Nilai BEP penerimaan adalah Rp456.069.661,74 per hektar dan Nilai BEP produksi $29.528,89 \mathrm{~kg}$ per hektar dengan harga jual Rp10.582,28 per kg.

\section{Pendapatan Rumah Tangga}

Rata-rata pendapatan rumah tangga pembudidaya lele di Kecamatan Natar Kabupaten Lampung adalah Rp52.340.376,00 per tahun. Distribusi pendapatan tersebut terdiri dari usaha budidaya lele sebesar Rp21.733.376 (44,27\%), usaha pertanian selain lele sebesar Rp11.707.000,00 (20,51\%), dan luar pertanian sebesar Rp18.900.000,00 (35,22\%). Persentase pendapatan budidaya lele yang cukup besar membuktikan bahwa usaha ini telah mampu memenuhi sebagian besar kebutuhan rumah tangga pembudidaya.

\section{Kesejahteraan Rumah Tangga Pembudidaya}

Tingkat kesejahteraan dapat diukur dengan pendekatan dari berbagai kriteria. Pada penelitian ini kriteria yang digunakan adalah kriteria Sajogyo, BPS, dan BKKBN.

\section{a. Kriteria Sajogyo}

Tingkat kesejahteraan rumah tangga pembudidaya yang diukur menggunakan kriteria Sajogyo (1997) dengan mengonversikan total pengeluaran rumah tangga per kapita per tahun dengan harga beras yang berlaku. Harga beras yang digunakan adalah Rp11.650,00 per kg dari harga beras rata-rata yang digunakan pembudidaya lele sebagai responden.

Pengeluaran rata-rata rumah tangga pembudidaya lele sebesar Rp51.480.717,00 per tahun. Pengeluaran tersebut terdiri dari pengeluaran pangan sebesar 33,05 persen, pengeluaran nonpangan 40,22 persen, pengeluaran tabungan 11,50 persen, pengeluaran arisan/cicilan 13,62 persen, dan pengeluaran sosial 1,65 persen. Sebaran responden berdasarkan tingkat pengeluaran dengan kriteria Sajogyo ditunjukkan pada Gambar 1.

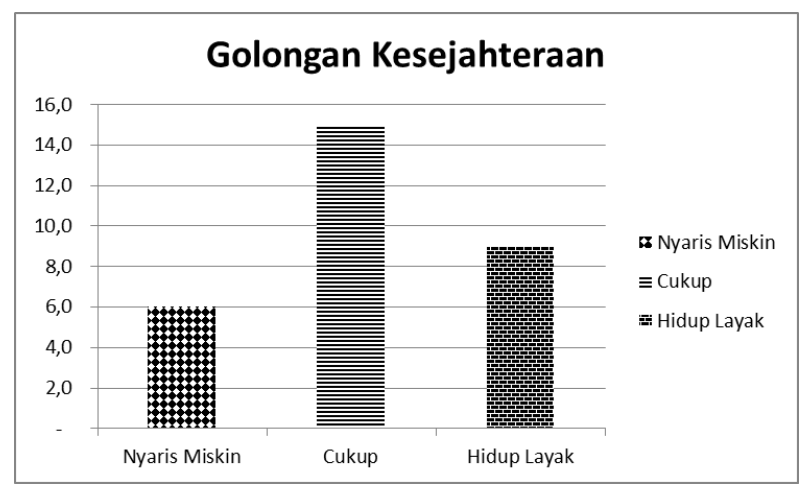

Gambar 1. Golongan kesejahteraan pembudidaya lele di Kecamatan Natar Kabupaten Lampung Selatan menurut kriteria Sajogyo (1997) $(\mathrm{n}=30)$

Pengeluaran rumah tangga golongan nyaris miskin antara Rp4.199.875,00-5.576.625,00 per orang per tahun atau setara dengan $361-479 \mathrm{~kg}$ per orang per tahun. Golongan cukup memiliki pengeluaran rumah tangga antara Rp5,947,250,0011.016.900,00 per orang per tahun atau setara 510 $946 \mathrm{~kg}$ per orang per tahun. Golongan hidup layak memiliki pengeluaran rumah tangga antara Rp11.443.000,00-41.693.000,00 per orang per tahun atau setara beras $982-3.579 \mathrm{~kg}$ per orang per tahun.

Usaha di bidang perikanan membutuhkan modal yang besar, sehingga pada umumnya masyarakat yang melakukan usaha ini adalah golongan rumah tangga sejahtera. Hal ini sejalan dengan penelitian Fadilah, Abidin dan Kalsum (2014) pada rumah tangga nelayan obor di Kota Bandar Lampung. Pada penelitian tersebut menunjukkan bahwa 74,42 persen rumah tangga nelayan masuk dalam golongan cukup dan 16,28 persen masuk dalam golongan hidup layak.

\section{b. Kriteria Badan Pusat Statistik}

Berdasarkan kriteria kesejahteraan BPS menunjukkan bahwa 20 persen rumah tangga responden masuk dalam golongan belum sejahtera, 80 persen lainnya masuk dalam golongan sejahtera. Tingkat kesejahteraan BPS diukur dengan pendekatan dari berbagai indikator. Indikator tersebut terdiri dari kependudukan, kesehatan dan gizi, pendidikan, ketenagakerjaan, taraf dan pola konsumsi, perumahan dan lingkungan, serta sosial dan lainnya. Perolehan skor rata-rata tiap indikator disajikan pada Tabel 2. 
Tabel 2. Rata-rata skor indikator kesejahteraan BPS

\begin{tabular}{lcc}
\hline \multicolumn{1}{c}{ Indikator } & Skor & Keterangan \\
\hline Kependudukan & 2 & Cukup \\
Kesehatan dan Gizi & 2 & Cukup \\
Pendidikan & 3 & Baik \\
Ketenagakerjaan & 2 & Cukup \\
Taraf dan Pola Konsumsi & 3 & Baik \\
Perumahan dan Lingkungan & 3 & Baik \\
Sosial dan lain-lain & 2 & Cukup \\
\hline Rata-rata & 14 & Sejahtera \\
\hline
\end{tabular}

Data pada Tabel 2 menunjukkan bahwa responden memperoleh skor cukup dan baik untuk ketujuh indikator kesejahteraan, dengan rata-rata total skor 17. Hasil perolehan total skor membuktikan bahwa sebagian besar pembudidaya telah masuk dalam kriteria kesejahtera. Sejalan dengan penelitian Sari, Haryono dan Rosanti (2014) tentang pendapatan dan tingkat kesejahteraan rumah tangga petani jagung di Kecamatan Natar di mana 71 persen responden berada dalam golongan sejahtera. Hal ini karena Kecamatan Natar berada di daerah yang cukup strategis dalam perekonomian yaitu dekat dengan pusat pasar Kota Bandar Lampung.

\section{c. Kriteria BKKBN}

Kesejahteraan menurut kriteria ini dibagi dalam lima tahapan keluarga yaitu pra sejahtera, sejahtera I, sejahtera II, sejahtera III, dan sejahtera III plus (BKKBN 2011). Sebanyak 20 persen rumah tanggga responden masuk pada tahapan keluarga pra sejahtera. Hal ini berarti rumah tangga tersebut belum mampu memenuhi kebutuhan dasarnya.

Sebanyak 50 persen responden masuk pada tahapan Keluarga Sejahtera (KS) I. Hal ini berarti bahwa sebagian besar rumah tangga pembudidaya telah memenuhi kebutuhan dasar namun belum mampu memenuhi kebutuhan psikologis. .KS II sebanyak 16,67 persen, artinya rumah tangga tersebut telah memenuhi kebutuhan dasar dan psikologis. Namun belum memenuhi kebutuhan perkembangannya. KS III sebanyak 10 persen, artinya rumah tangga tersebut telah memenuhi kebutuhan dasar, psikologis, dan perkembangannya. KS III Plus sebanyak 3,33 persen, artinya rumah tangga tersebut telah memenuhi kebutuhan dasar, psikologis, perkembangan, dan aktualisasi diri. Sebaran rumah tangga responden menurut kriteria BKKBN tersaji pada Gambar 2.

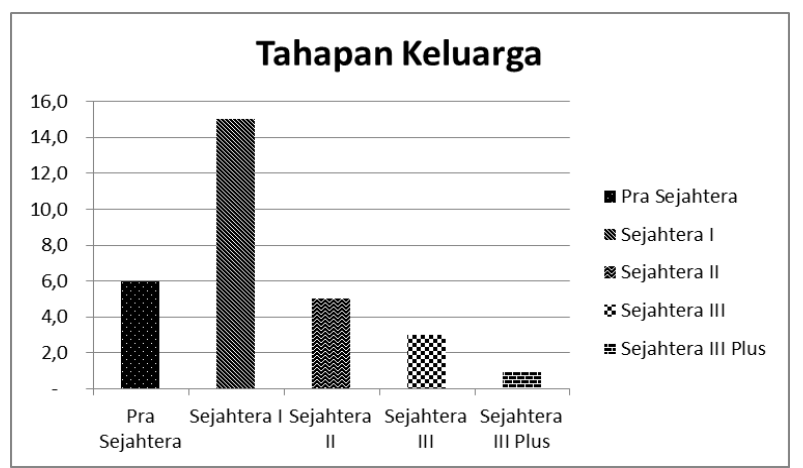

Gambar 2. Tahapan keluarga pembudidaya lele di Kecamatan Natar Kabupaten Lampung Selatan menurut kriteria $\operatorname{BKKBN}(\mathrm{n}=30)$

Kriteria Sajogyo, BPS, dan BKKBN menggunakan ukuran kesejahteraannya tidak sama. Perbandingan tingkat kesejahteraan dengan kriteria Sajogyo dan BPS menunjukkan bahwa terdapat 20 persen rumah tangga golongan nyaris miskin pada kriteria Sajogyo dan belum sejahtera pada kriteria BPS. Rumah tangga golongan cukup dan hidup layak pada kriteria Sajogyo termasuk ke dalam golongan sejahtera pada kriteria BPS. Hal ini berarti rumah tangga tersebut telah mengalokasikan cukup dana yang dibutuhkan pada variabel kependudukan, kesehatan dan gizi, pendidikan, ketenagakerjaan, serta taraf dan pola konsumsi. Perbandingan kriteria Sajogyo dan BPS disajikan pada Gambar 3.

Perbandingan kriteria BKKBN dan BPS menunjukkan bahwa 20 persen rumah tangga pembudidaya masuk ke dalam golongan pra sejahtera pada kriteria BKKBN sekaligus golongan belum sejahtera pada kriteria BPS. Pada kriteria BKKBN rumah tangga dikatakan belum sejahtera karena belum memenuhi seluruh kebutuhan dasarnya. Kebutuhan dasar tersebut adalah tempat tinggal dengan kondisi fisik baik dan penggunaan sarana kesehatan. Pada kriteria BPS rumah tangga yang masuk dalam golongan belum sejahtera karena belum memenuhi kebutuhan hiburan dan rekreasi, serta ketidakpahaman menggunakan komputer. Rumah tangga yang masuk ke dalam golongan sejahtera pada kriteria BPS dan BKKBN berarti telah memenuhi ketujuh variabel kesejahteraan BPS dan kebutuhan dasar BKKBN. Perbandingan kriteria BKKBN dan BPS disajikan pada Gambar 4. 


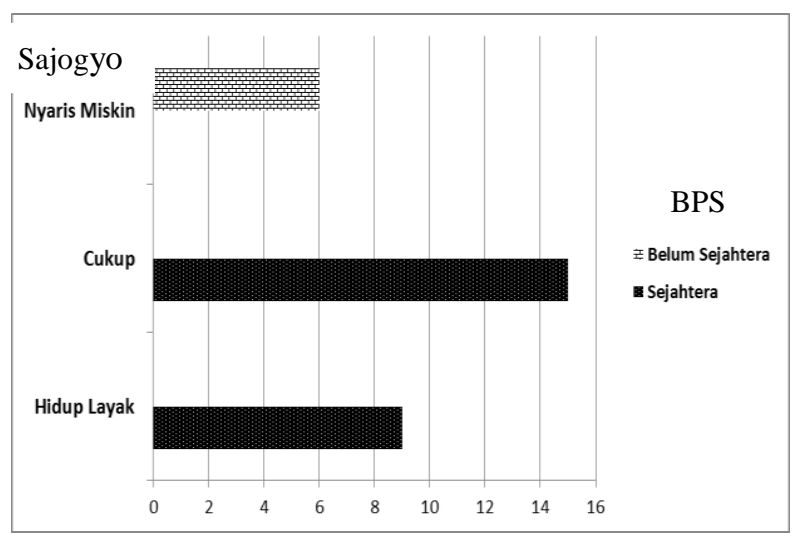

Gambar 3. Perbandingan antara kriteria Sajogyo dan BPS $(n=30)$

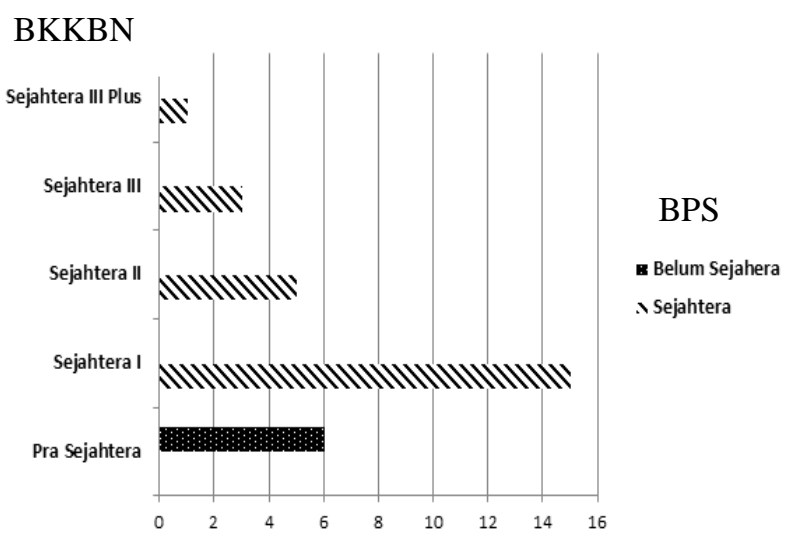

Gambar 4. Perbandingan antara kriteria BKKBN dan BPS $(n=30)$

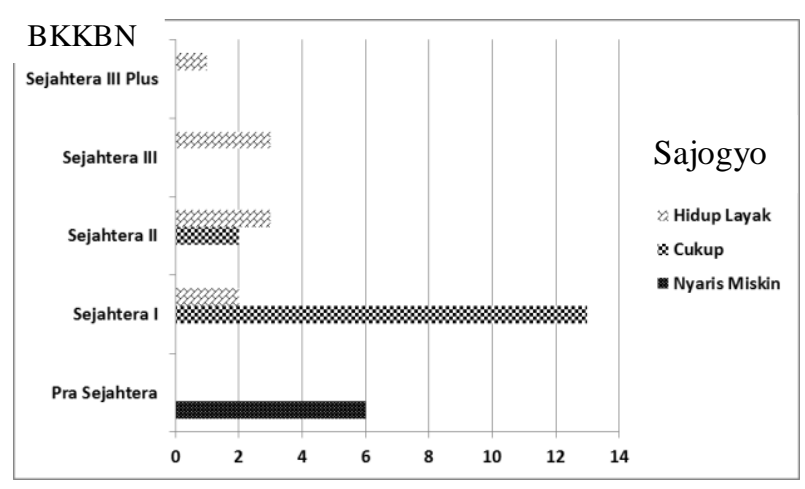

Gambar 5. Perbandingan antara kriteria BKKBN dan Sajogyo $(n=30)$

Perbandingan kriteria yang tersaji pada Gambar 5 menunjukkan bahwa 20 persen rumah tangga pembudidaya masuk dalam golongan non sejahtera yaitu nyaris miskin dalam kriteria Sajogyo dan pra sejahtera dalam kriteria BKKBN. Hal ini berarti bahwa sebesar 20 persen rumah tangga pembudidaya belum mengalokasikan cukup dana untuk memenuhi kebutuhan dasarnya. Rumah tangga yang masuk dalam golongan cukup pada kriteria Sajogyo termasuk ke dalam golongan Keluarga Sejahtera I dan II yaitu sebesar 50 persen. Hal ini berarti bahwa rumah tangga golongan cukup telah memenuhi kebutuhan dasar dan psikologisnya.

Rumah tangga yang masuk dalam golongan hidup layak pada kriteria Sajogyo termasuk dalam golongan yang beragam dalam kriteria BKKBN.

Rumah tangga yang masuk dalam golongan hidup layak dan keluarga sejahtera I berarti telah memenuhi kebutuhan secara finansial namun belum memenuhi kebutuhannya secara psikologis. Kebutuhan tersebut adalah kemampuan baca tulis dari usia 10 - 60 tahun dan penggunaan alat kontrasepsi. Rumah tangga yang masuk dalam golongan hidup layak dan keluarga sejahtera II berarti telah memenuhi kebutuhannya secara finansial, serta kebutuhan dasar dan psikologis. Akan tetapi rumah tangga tersebut belum memenuhi kebutuhan perkembangan seperti peningkatan pengetahuan agama dan keikutsertaan dalam lingkungan masyarakat. Rumah tangga yang masuk dalam golongan hidup layak dan keluarga sejahtera III berarti telah memenuhi kebutuhannya secara finansial, serta kebutuhan dasar, psikologis, dan perkembangan. Rumah tangga yang masuk ke dalam golongan hidup layak dan keluarga sejahtera III plus berarti telah memenuhi kebutuhannya secara finansial, serta kebutuhan dasar, psikologis, pengembangan, dan aktualisasi diri. Kebutuhan aktualisasi diri meliputi sumbangan materiil untuk kegiatan sosial dan menjadi pengurus organisasi sosial.

\section{KESIMPULAN}

Pendapatan total rata-rata rumah tangga pembudidaya lele di Kecamatan Natar Kabupaten Lampung Selatan adalah Rp52.340.376,00 per tahun. Pendapatan tersebut terdiri dari 44,27 persen pendapatan usaha budidaya lele, 20,51 persen pendapatan pertanian di luar lele, dan 35,22 persen di luar pertanian. Berdasarkan analisis tingkat kesejahteraan dengan kriteria Sajogyo diketahui bahwa 20 persen rumah tangga pembudidaya berada dalam golongan nyaris miskin, 50 persen rumah tangga di golongan cukup, dan 30 persen rumah tangga di golongan hidup layak. Kriteria BPS menunjukkan bahwa 20 persen pembudidaya merupakan golongan rumah tangga belum sejahtera dan 80 persen golongan keluarga sejahtera. Kriteria BKKBN menunjukkan bahwa keluarga pembudidaya terdiri dari 20 persen golongan pra sejahtera, 50 persen 
golongan sejahtera I, 16,67 persen golongan sejahtera II, 10 persen golongan sejahtera III, dan 3,33 persen golongan sejahtera III plus.

\section{DAFTAR PUSTAKA}

BKKBN [Badan Kependudukan dan Keluarga Berencana]. 2011. Batasan dan Pengertian $M D K$. Badan Kependudukan dan Keluarga Berencana. Jakarta. http://aplikasi.bkkbn. go.id/ mdk/BatasanMDK.aspx. [12 November 2017].

BPS [Badan Pusat Statistik]. 2014. Indikator Kesejahteraan Rakyat. Badan Pusat Statistik. Jakarta. https://www.bps.go.id/. [10 November 2017].

BPS [Badan Pusat Statistik]. 2017. Jumlah Perahu/Kapal, Luas Usaha Budidaya dan Produksi menurut Sub Sektor Perikanan, 2002-2015. Badan Pusat Statistik. Jakarta. https://www.bps.go.id/. [25 November 2017].

Dinas Kelautan dan Perikanan Provinsi Lampung . 2017a. Produksi Ikan Tawar Kolam Menurut Jenis Ikan Provinsi Lampung 2016. Dinas Kelautan dan Perikanan Provinsi Lampung. Bandar Lampung.

Dinas Kelautan dan Perikanan Provinsi Lampung . 2017b. Produksi Ikan Lele Menurut Kabupaten/Kota di Provinsi Lampung 2016. Dinas Kelautan dan Perikanan Provinsi Lampung. Bandar Lampung.

Dinas Kelautan dan Perikanan Lampung Selatan. 2017a . Daftar Pokdakan Ikan Lele di Kecamatan Natar 2016-2017. Dinas Kelautan dan Perikanan Kabupaten Lampung Selatan. Kalianda.

Dinas Kelautan dan Perikanan Lampung Selatan. 2017b. Produksi Ikan Lele per Kecamatan di Lampung Selatan 2016. Dinas Kelautan dan Perikanan Kabupaten Lampung Selatan. Kalianda.

Febriyanti RE. 2013. Kontribusi pengembangan kawasan minapolitan kampung lele terhadap pendapatan petani lele di Desa Tegalrejo
Sawit Boyolali. Economics Development Analysis Journal. https://journal.unnes.ac.id/ sju/index.php/edaj/article/view/3208._[23April 2018].

Sajogyo T. 1997. Garis Kemiskinan dan Kebutuhan Minimum Pangan. LPSB-IPB. Bogor.

Suratiyah K. 2015. Ilmu Usahatani Edisi Revisi. Penebar Swadaya. Jakarta.

Rahim A dan Hastuti DRD. 2008. Ekonomika Pertanian. Penebar Swadaya. Jakarta.

Pemerintah Kota Bandar Lampung. 2017. Profil Kota Bandar Lampung. Pemerintah Kota Bandar Lampung. Bandar Lampung. https://bandarlampungkota.go.id/. [20April 2018].

Purwono J, Sugyaningsih S, dan Wibowo AE. 2011. Strategi pengembangan usaha pembesaran ikan Lele Sangkuriang (Clarias Gariepinus Strain Sangkuriang) (Kasus UKM budidaya lele) di Kecamatan Ciampea Kabupaten Bogor. Jurnal Agribisnis IPB Vol.01 (2): 1 - 11. http://docplayer.info/amp/ 43369885-Dosen-mkdu-ipb-3-alumi-agribis nis-fakultas-ekonomi-dan-manajemen-ipb-jlnlingkar-kampus-ipb-dramaga-ipb.html. April 2018].

Sari DK, Haryono D, dan Rosanti N. 2014. Analisis pendapatan dan tingkat kesejahteraan rumah tangga petani jagung di Kecamatan Natar Kabupaten Lampung Selatan. Jurnal Ilmu-ilmu Agribisnis Vol.01 (1) : 64-70. http://jurnal.fp.unila.ac.id/index./JIA/article/ view/562/524. [26 April 2018].

Supriyono RA. 2001. Akuntansi Biaya. BPFE Yogyakarta. Yogyakarta.

Susanti S, Lestari DAH dan Kasymir E. 2017. Sistem agribisnis ikan patin (Pangasius Sp.) kelompok budidaya ikan Sekar Mina di Kawasan Minapolitan Patin Kecamatan Kota Gajah Lampung Tengah. Jurnal Ilmu-ilmu Agribisnis Vol.05 (2) : 116 - 123. http:// jurnal.fp.unila.ac.id/index.php/JIA/article/vie w/1648/1474. [25April 2018]. 